\title{
Marital Satisfaction amongst Nigerian Immigrants in North America (NINA): Pilot Study
}

\author{
Jochebed B. Ade-Oshifogun ${ }^{1}$, Joan Aina ${ }^{1} \&$ Augusta Olaore ${ }^{2}$ \\ ${ }^{1}$ School of Nursing, Andrews University, Berrien Springs, MI, USA \\ ${ }^{2}$ Babcock University, Ilishan-Remo, Nigeria \\ Correspondence: Samuel P. Abraham, Bethel University School of Nursing, 1001 Bethel Circle, Mishawaka, \\ Indiana, 46545, USA.
}

Received: June 24, 2019

Accepted: July 12, 2019

Online Published: July 17, 2019

doi:10.20849/ajsss.v4i2.608

URL: https://doi.org/10.20849/ajsss.v4i2.608

\begin{abstract}
Background: It has been observed that some Nigerian Families that immigrated to North America (NINA) seem to have very stressful marital relationships that lead to separation or divorce. The goal of this study was to determine the level of marital satisfaction among NINA
\end{abstract}

Method: A simple, standardized survey tool was utilized to measure the index of marital satisfaction (IMS). The score varied from 0-100 with a lower score ( $<30$ points) indicating marital satisfaction. A demographic questionnaire was also administered to the subjects. Descriptive data analysis and level of marital satisfaction were computed in SPSS (version 25).

Results: Forty-five of the fifty questionnaires were returned completed. Fifty-one percent of respondents were female. The majority (44\%) were between the ages of $41-50$ years. $81 \%$ were married and living with spouses. Average year of marriage was 13.5 years. The majority $(85 \%)$ of respondents were married in Nigeria with only one spouse immigrating first $(35 \%)$. The primary reason for immigration was employment for most subjects (48\%). Seventy-two percent of the respondents scored $<30$ on the IMS scale, indicating marital satisfaction. The scores were not significant when compared within the demographic variable groups. Most participants (71.4\%) reported significant marital satisfaction $(\mathrm{Z}=-3.209, \mathrm{p}=0.001 . \mathrm{r}=0.47)$.

Conclusion: Initial pilot study did not support the observation in the Nigeria community regarding stressful marital relationships among NINA. The IMS tool may not be sensitive to the Nigerian marriage culture and possible factors affecting marital satisfaction with cultural influence. The authors plan to conduct a more extensive study with a qualitative approach to elicit the Nigerian culturally sensitive factors.

Keywords: Index of Marital Satisfaction (IMS), marital satisfaction, immigrants, Nigeria, Seventh Day Adventist (SDA), West Africa, North America

\section{Introduction}

Reports indicate that Africans, Nigerians included, consist of a small, but growing segment of the United States immigrant population and since 1970 the number of immigrants has been doubling every decade (Anderson, 2017). Africans are one of the fastest growing groups migrating to the U.S., which is apparent by the increase of $137 \%$ between 2000 and 2013 (Anderson, 2017). Anderson and Lopez (2018) shared that the black African immigrants' population more than doubled in the U.S, from 574,000 to 1.6 million, between 2000 and 2016. The census data also indicated that $35 \%$ of African Immigrants originated from West Africa of which over a third (38.7\%) are from Nigeria while the rest are from Ethiopia, Ghana, Kenya, and Egypt. The largest African Immigrant populations are found in California, New York, Texas, Maryland and Virginia.

Studies conducted in the past provide substantial evidence that Nigerian immigrants who live in the United States, are often in situations that lead to stress for married couples. Issues arising from internal and external conflicts may grow as more Nigerians migrate. The dream of a better life is a reason that Nigerian immigrants leave their home country. The reputation of another country, like the United States, attracts millions (Woodgate, et al., 2017). The reality is that they are often oblivious of the challenges or obstacles that families can face.

Bucher-Maluschke, Gondim, and Pedroso (2017) presented an analogy that was based on a qualitative study that 
focused on the emotional and mental effects of being immigrants. It was shared that "migration turns into one of the contingencies of life that can cause psychological disorganization" (Bucher-Maluschke et al., 2017). When people move their residence from one country to another, they face realities that Obikor \& Afolayan (2007) described as "age-long cargo of dilemma." Immigrants generally have to wrestle with cultural conflicts, culture shock, and intergenerational contestation. Donkor (2012) observed that the "act of Immigration" amongst Ghanaian Immigrants required adjustments and radical shifts in perceptions, aspirations, desires, and expectations.

Immigrant families living in the United States of America generally experience stressors that directly impact family functioning Obiakor \& Afolayan (2007) posited that while Africans living in Africa have their portion of challenges. Africans living in America have more stringent burdens that erode resiliency which leads to high-stress levels and high rates of divorce.

The immigrant Nigerian family unit struggles to maintain a balance between growing individually and maturing concerning the area's system. One coping strategy that immigrants use to meet the challenges is clustering (Hamilton, Easley, \& Dixon, 2018). This means marriage partners who migrate together seek jobs in geographic areas that bring a level of comfort and acceptance. In these areas the immigrant families can hold on to some of the cultural ways of dressing, eating, celebrating and expressing themselves, which help them to maintain strong marriage ties (Hamilton, Easley, \& Dixon, 2018). Another study focused on how the marriages of African immigrants were influenced by race-ethnicity, generational status, and first marriage (Thomas, 2017). Thomas (2017) commented that "as assimilation increases, immigrants are less likely to have outcomes that are consistent with a retreat from marriage" (p. 1278).

This study, therefore, sought to add knowledge that will foster a better understanding of the marital challenges faced by NINAs as a significant immigrant population in North America.

\section{Methodology}

This was a cross-sectional pilot study utilizing a standardized survey tool (Index of Marital Satisfaction-IMS). Research approval was obtained from the Chicago State University Institutional Review Board, where the Principal Investigator was working at the time of the data collection. The participants were all Nigerians, married, or previously married to a Nigerian and resident in North America for at least one year by the time of data collection.

Sixty-five questionnaires were administered during a Nigerian camp meeting in Michigan. This was a convenience sample of subjects interested in completing the survey after the study was introduced at the camp meeting. The total number of adult campers was 76 . The camp meeting was a church organized meeting where the majority were Seventh Day Adventists and $<5 \%$ of campers were members of a different denomination or religion. The completion of the survey questionnaire implied consent. A study description with implied consent information was attached as the first page of the survey tool.

The IMS is a 25-item scale developed by Hudson (1997). The tool utilized a 5-point Likert format, with responses ranging from 1 (strongly disagree) to 5 (strongly agree). Examples of items on the tool include: "'my partner treats me badly;" and "I feel that I no longer care for my partner." IMS has demonstrated a high level of reliability (a $=.96$ ), with a test-retest correlation of .96 (Hudson 1997). The score varied from 0-100 with a lower score $(<30$ points) indicating marital satisfaction. Participants also completed a demographic questionnaire showing their age, years of marriage, who migrated first, where the marriage was contracted, primary reason for immigration, and length of stay in the USA before uniting with a spouse if applicable.

Data analysis was completed using SPSS (version 25). Descriptive statistics were done on demographic variables. Because the IMS score variable was not normally distributed, a one sample Sign Test was conducted to determine if observed NINA scored significantly less than 30 points on their IMS. The median IMS scores between the different demographic groups were also compared using the Mann-Whitney and Kruskal-Wallis Tests.

\section{Results}

Table 1 highlights the demographics of the participants of this pilot study. Majority of the respondents were females (51\%). There were older and younger age groups responding to the questionnaire with the majority (44\%) between the ages of 41-50 years. The participants were all married, and most lived with their spouse (81\%). Only four subjects claimed to be married but emotionally separated from a spouse. The average length of marriage in this study was $13.5 \pm 11.6$ years, with $41 \%$ of respondents married for over 20 years. Eighty-five percent of the marriages were contracted in Nigeria with only four marriages contracted in the USA. Most respondents either immigrated alone (36\%) first or with spouse (32\%) to the United States of America. The primary reason for immigration was employment (48\%) followed by education (32\%). 
Table 1. Demographics of study participants

\begin{tabular}{|c|c|}
\hline Characteristics & $\mathrm{N}(\%)$ \\
\hline \multicolumn{2}{|l|}{ Gender $(\mathrm{N}=45)$} \\
\hline Male & $22(48.9)$ \\
\hline Female & $23(51.1)$ \\
\hline \multicolumn{2}{|l|}{ Age group $(\mathrm{N}=47)$} \\
\hline $20-30$ & $2(4.4)$ \\
\hline $31-40$ & $7(15.6)$ \\
\hline $41-50$ & $20(44.4)$ \\
\hline $51-60$ & $10(22.2)$ \\
\hline Above 60 & $6(13.3)$ \\
\hline \multicolumn{2}{|l|}{ Marital status $(\mathrm{N}=45)$} \\
\hline Married and living with spouse & $38(80.9)$ \\
\hline Married, spouse living in Nigeria & $5(10.6)$ \\
\hline Married and living together but emotionally separated & $4(8.5)$ \\
\hline \multicolumn{2}{|l|}{ Years of marriage $(\mathrm{N}=45)$} \\
\hline $1-5$ & $7(15,2)$ \\
\hline $6-10$ & $2(4.3)$ \\
\hline $11-15$ & $9(19.6)$ \\
\hline $16-20$ & $9(19.6)$ \\
\hline Over 20 & $19(41.3)$ \\
\hline \multicolumn{2}{|l|}{ Marriage Contracted $(\mathrm{N}=44)$} \\
\hline Nigeria & $37(84.6)$ \\
\hline USA & $4(9.1)$ \\
\hline Other & $3(6.8)$ \\
\hline \multicolumn{2}{|l|}{ Who Immigrated First $(\mathrm{N}=44)$} \\
\hline Self & $16(36.4)$ \\
\hline Spouse & $14(31.8)$ \\
\hline Together & $13(29.5)$ \\
\hline Child(children) & $1(2.3)$ \\
\hline \multicolumn{2}{|l|}{ First Immigration Reason $(\mathrm{N}=44)$} \\
\hline Education & $14(31.8)$ \\
\hline Employment & $21(47.7)$ \\
\hline To help relatives & $9(20.5)$ \\
\hline
\end{tabular}

There was no significant difference in marital satisfaction scores between male and female participants; the different age groups; and years of marriage. The marital status, where the marriage was contracted, who immigrated first, and the reason for immigration did not make a significant difference for the IMS scores (See Table 2 below). 
Table 2. Median scores of marital satisfaction by demographic characteristics of participants

\begin{tabular}{|c|c|c|c|c|}
\hline Characteristics & $\mathrm{N}(\%)$ & Median IMS Score & Statistics & P Value \\
\hline \multicolumn{5}{|l|}{ Gender } \\
\hline Male & $22(44.7)$ & 12.3 & $U=243, \mathrm{r}=0.005$ & 0.829 \\
\hline Female & $23(55.3)$ & 18.0 & & \\
\hline \multicolumn{5}{|l|}{ Age group $(\mathrm{N}=47)$} \\
\hline $20-30$ & $2(4.4)$ & 3.7 & $H=8.31$ & 0.81 \\
\hline $31-40$ & $7(15.6)$ & 12.0 & $\mathrm{df}=4$ & \\
\hline $41-50$ & $20(44.4)$ & 19.0 & & \\
\hline $51-60$ & $10(22.2)$ & 9.3 & & \\
\hline Above 60 & $6(13.3)$ & 30 & & \\
\hline \multicolumn{5}{|l|}{ Marital status $(\mathrm{N}=45)$} \\
\hline Married and living with spouse & $38(80.9)$ & 10.0 & $H=2.02$ & 0.363 \\
\hline Married, spouse living in Nigeria & $5(10.6)$ & 12.0 & $\mathrm{df}=2$ & \\
\hline $\begin{array}{l}\text { Married and living together but } \\
\text { emotionally separated }\end{array}$ & $4(8.5)$ & 21.7 & & \\
\hline \multicolumn{5}{|l|}{ Years of marriage $(\mathrm{N}=45)$} \\
\hline $1-5$ & $7(15,2)$ & 7.33 & $H=3.347$ & 0.505 \\
\hline $6-10$ & $2(4.3)$ & 16.7 & $\mathrm{df}=4$ & \\
\hline $11-15$ & $9(19.6)$ & 38.7 & & \\
\hline $16-20$ & $9(19.6)$ & 11.3 & & \\
\hline Over 20 & $19(41.3)$ & 12.0 & & \\
\hline \multicolumn{5}{|l|}{ Marriage Contracted $(\mathrm{N}=44)$} \\
\hline Nigeria & $37(84.6)$ & 14.7 & & \\
\hline USA & $4(9.1)$ & 4.3 & $H=2.63$ & 0.625 \\
\hline Other & $3(6.8)$ & 38.7 & $\mathrm{df}=2$ & \\
\hline \multicolumn{5}{|l|}{ Who Immigrated First $(\mathrm{N}=44)$} \\
\hline Self & $16(36.4)$ & 10.0 & & \\
\hline Spouse & $14(31.8)$ & 19.7 & $H=1.238$ & 0.744 \\
\hline Together & $13(29.5)$ & 19.3 & $\mathrm{df}=3$ & \\
\hline Child(children) & $1(2.3)$ & - & & \\
\hline \multicolumn{5}{|l|}{ First Immigration Reason $(\mathrm{N}=44)$} \\
\hline Education & $14(31.8)$ & 21.0 & $H=1.877$ & 0.391 \\
\hline Employment & $21(47.7)$ & 19.3 & $\mathrm{df}=2$ & \\
\hline To help relatives & $9(20.5)$ & 10.0 & & \\
\hline
\end{tabular}

U: Mann-Whitney Test; H: Kruskal-Wallis Test

The analysis of data received showed that seventy one percent of respondents reported marital satisfaction with the IMS scores $(<30)$. Twenty four percent or 12 respondents had clinically significant problems with their marriages as indicated by IMS interpretation of scores (see Table 3). The one sample sign test indicated that the median NINA scores $(\mathrm{Mdn}=14.7)$ were significantly lower than the IMS 30 points cutoff, with a small to moderate effect size $(Z=-3.209, p=0.001 . r=0.47)$. 
Table 3. Number of participants by level of marital satisfaction

\begin{tabular}{lll}
\hline Characteristics & Score & $n(\%)$ \\
\hline Free of clinically significant problem & $<30$ & $35(71.4)$ \\
\hline Have clinically significant problem & 30 and above & $12(24.5)$ \\
\hline
\end{tabular}

\section{Discussion}

This study attempted to capture marital satisfaction in one survey using the IMS tool. It is important to stress that one cross-sectional survey may not fully capture marital satisfaction by spouses because present situations usually shape human experience and not necessarily by a trajectory of fluctuations in marital evaluations over time (Bradbury, Fincham, \& Beach, 2000). Nonetheless, a cross-sectional survey is useful for having a glimpse into the experience of the participants and will inform the authors regarding the trajectory of future studies in this area. Presently, there is a paucity of literature addressing this vital issue.

In this study, the experience of Nigerians immigrating to the United States of America had been explored regarding the impact of this immigration on their marital relationship. The authors did not separate or control for factors that may influence the marital satisfaction irrespective of immigration. The pilot study was aimed at giving the authors a perspective for a future more extensive research. In Africa, though marriage could be polygamous, the participants in this study have monogamous marriages partly because of their educational preparation, religious affiliation, and the law in the country they immigrated to (USA).

The survey tool (IMS) to our knowledge had not been widely used in studies with African population, therefore, we critiqued its cultural sensitivities for this population. We observed cultural differences not addressed by the IMS tool. According to Ngazimbi (2009), socio-cultural factors that impact marriages from the home country may continue to impact marriages in the diaspora. Examples of such factors include the patriarchal systems affecting financial control, in-law relationships, and respect for the husbands. These factors were not included in the IMS questionnaire. Therefore, the authors realized the need to design a culturally sensitive tool for the Nigerian immigrant population or explore other available tools.

In this pilot study, there was no significant impact of demographic factors like gender and years of marriage. Likewise, in the study by Edwin (2017), age, gender, and years of experience were not significant predictors of marital satisfaction. In another study by Omolayo, Falegan, \& Ajila, (2013), they also observed that years of marriage had no influence om marital conflict. The study by Idemudia \& Ndlovu (2013) however, found significant differences between men and women on three out of their four marital satisfaction subscales. They conducted their study using South Africans, which may account for some of the difference in results. If these demographic factors were not significant for marital satisfaction, there must be other factors not captured by the tool. The authors will continue to explore these factors in future studies.

The total IMS score was utilized to interpret the level of marital satisfaction. According to the authors of the tool, an overall score of less than 30 is interpreted as 'free of the clinically significant problem' or having marital satisfaction. In this study, $71 \%$ of participants reported marital satisfaction. This was a very positive result, and it is comparable to the results obtained from the study of public servants in Cross River State, Nigeria. The authors reported marital satisfaction to be significantly high. Some of the factors reported by the authors to substantially influence marital satisfaction include the number of children, communication, and time spent together (Adigeb \& Mbua, 2015).

This study was conducted at the Nigerian Adventist in North America (NANA) annual camp. The Seventh Day Adventist church promotes family unity and does not encourage divorce (S.D.A Church, 2019). This may account for the higher percentage of marital satisfaction in this study. In their study of a relational approach to religion and spirituality in marriage, David \& Stafford (2015) reported an individual relationship with God as critical to marital quality because it encourages communication between partners and forgiveness. Interestingly, they concluded that joint religious communication is more strongly associated with satisfaction with mixed-faith compared to same-faith couples. The religious background did not factor into marriage instability between couples with different religious background (Animasahun \& Fatile, 2011). This phenomenon was not investigated in our study, however, more than eighty percent of the participants are of the same faith, and it is believed that religion possibly played a role in the high percentage of marital satisfaction within the group studied. Though not significant, the small number of participants with clinically significant problems should be counseled. The authors believe that marital counseling should also address pertinent cultural issues. 
Limitations of the study include its small sample size and the homogenous religious group, which makes it non-generalizable to the Nigerian population in North America. The authors submit that the IMS tool is not sensitive to the cultural aspects of Nigerian marriage and may not adequately capture the areas of dissatisfaction in the marriages.

\section{Conclusion}

This was a pilot study to investigate marital satisfaction among Nigerians living in North America. The results of the study showed that the number of participants with marital satisfaction is significantly more than the number with marital problems. Various demographic factors' comparisons did not show any significant difference in the level of marital satisfaction scores. Though the sample size for this pilot study was small, it was an eye-opener for follow up research in this area. There is a dearth of literature addressing the concept studied in the context of Nigerian Immigrants, and information gleaned from the research will add to the body of knowledge. The findings from this study highlight the need for culturally sensitive tools to measure marital satisfaction among people of African heritage, taking into consideration cultural factors. The perceived notion of marital dissatisfaction among Nigerians living in North America needs further exploration because the pilot study did not corroborate this notion.

\section{References}

Adigeb, A. P., \& Mbua, A. P. (2015). The Influence of Psychosocial Factors on Marital Satisfaction Among Public Servants in Cross River State. Global Journal of Human-Social Science, 15(8). Retrieved from https://globaljournals.org/GJHSS_Volume15/2-The-Influence-of-Psychosocial-Factors.pdf

Akinsulure-Smith, A. M., Chu, T., Keatley, E., \& Rasmussen, A. (2013). Intimate partner violence among West African immigrants. Journal of Aggression, Maltreatment \& Trauma, 22(1), 109-129. http://doi.org/10.1080/10926771.2013.719592

Anderson, M., \& Lopez. (2018). Key facts about black immigrants in the U.S. Pew Research Center. Retrieved from http://www.pewresearch.org/fact-tank/2018/01/24/key-facts-about-black-immigrants-in-the-u-s/

Anderson, M. (2017). African immigrant population in U.S. steadily climbs. Pew Research Center. Retrieved from http://www.pewresearch.org/fact-tank/2017/02/14/african-immigrant-population-in-u-s-steadily-climbs/

Animasahun, R. A., \& Fatile, E. A. F. (2011). Patterns of marital instability among married couples in Lagos, Nigeria. Journal of African Studies and Development, 3(10), 192-199. Retrieved from http://www.academicjournlas.org/JASD

Bradbury, T. N., Fincham, F. D., \& Beach, S. R. H. (2000). of Marital on the Nature and Determinants A Decade in Review Satisfaction : Family Relations, 62(4), 964-980.

Browne, D. T., Kumar, A., Puente-Duran, S., Georgiades, K., Leckie, G., \& Jenkins, J. (2017). Emotional problems among recent immigrants and parenting status: Findings from a national longitudinal study of immigrants in Canada. PLoS ONE, 12(4), e0175023. https://doi.org/10.1371/journal.pone.0175023

Bucher-Maluschke, J., Gondim, M., \& Pedroso, J. (2017). The effects of migration on family relationships: Case studies. International Journal of Migration, Health and Social Care, 13(2), 198-206. https://doi.org/10.1108/IJMHSC-05-2015-0016

David, P., \& Stafford, L. (2015). A Relational Approach to Religion and Spirituality in Marriage: The Role of Couples' Religious Communication in Marital Satisfaction. Journal of Family Issues, 36(2), 232-249. https://doi.org/10.1177/0192513X13485922

Donkor, M. (2013). "I'm Divorcing Because I Drank Lake Ontario": Marital Breakdown in Ghanaian Immigrant Families in Toronto. Southern Journal of Canadian Studies, 5(1).

Edwin, O. A. A. (2017). Personality traits and sexual satisfaction as determinants of marital satisfaction among couples in Ibadan. Gender \& Behaviour, 15(1), 8421-8441. Retrieved from https://search.proquest.com/docview/1925704043/fulltextPDF/9D63ECC4A2340E9PQ/16?accountid=1477 7

Ejekam, E. (2014). Are Nigerian marriages in America on the brink of extinction? Retrieved from http://www.nairaland.com/1795439/nigerian-marriages-america-brink-extinction

Hamilton, T. G., Easley, J. A., \& Dixon, A. R. (2018). Black immigration, occupational niches, and earnings disparities between U. S.-born and foreign-born blacks in the United States. The Russell Sage Foundation Journal of the Social Sciences, 4(1), 60-77.

Hudson, W. W. (1997). The WALMYR assessment scales scoring manual. Tallahassee, FL: WALMYR Publishing 
Company.

Idemudia, S., \& Ndlovu, N. J. (2013). How Happy are Married People? Psychological Indicators of Marital Satisfaction of Married Men and Women in Gauteng Province, South Africa. Gender \& Behaviour, 11(2), 5486-5498. Retrieved

from https://ezproxy.usim.edu.my:2229/docview/1465230547/fulltextPDF/3B18A4F7241C49F8PQ/28?accounti $\mathrm{d}=33993$

Ikuomola, A. D. (2015). Unintended consequences of remittance: Nigerian migrants and intra-household conflicts. SAGE Open. https://doi.org/10.1177/2158244015605353

Jang, J. B., Casterline, J. B., \& Snyder, A. (2014). Migration and marriage: Modeling the joint process. Demographic Research, 30, 1339-1366. http://doi.org/10.4054/DemRes.2014.30.47

Ngazimbi, E. (2009). Exploring the Relationship Between Marital Expectations and Marital Satisfaction Between Married African Immigrant Couples and United States Born Married Couples. Journal of Psychology in Africa, 23(2), 189. https://doi.org/10.1080/14330237.2013.10820629

Obiakor, F. E., \& Afoláyan, M. O. (2007) African Immigrant Families in the United States: Surviving the Sociocultural Tide. The Family Journal: Counseling and Therapy for Couples and Families, 15(3), $265-270$.

Omolayo, B. O., Falegan, T., \& Ajila, C. K. (2013). Influence of job demand and employment status on marital conflict and marital satisfaction among women in Ekiti state, Nigeria. Journal of Psychology and Behavioral Science, 1(1), 8-18.

Oyekanmi, F. A. D., Eborka, K., \& Temilola, O. (2017). Family patterns in the context of international migration: Evidence from families of international migrants in Lagos, Nigeria. Advances in Social Sciences Research Journal, (423), 201-213.

Seventh Day Adventist Church [Marriage and Family website]. (n.d.). Retrieved June 18, 2019, from https://www.adventist.org/en/beliefs/living/marriage-and-the-family/

Thomas, D. (2017). Race, generational status, and the dynamics of first-marriage transitions among black immigrants in the United States. Journal of Family Issues, 39(5), 1258-1280. https://doi.org/10.1177/0192513X17698185

West, C. M. (2016) African immigrant women and intimate partner violence: A systematic review. Journal of Aggression, Maltreatment \& Trauma, 25(1), 4-17. https://doi.org/10.1080/10926771.2016.1116479

Woodgate, R. L., Busolo, D. S., Crockett, M., Dean, R. A., Amaladas, M. R., \& Plourde, P. J. (2017). A qualitative study on African immigrant and refugee families' experiences of accessing primary health care services in Manitoba, Canada: it's not easy! International Journal for Equity in Health, $16,5$. http://doi.org/10.1186/s12939-016-0510-x

\section{Copyrights}

Copyright for this article is retained by the author(s), with first publication rights granted to the journal.

This is an open-access article distributed under the terms and conditions of the Creative Commons Attribution license (http://creativecommons.org/licenses/by/4.0/). 